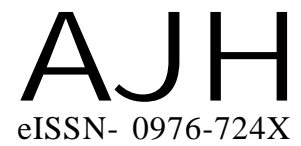

Received : 02.02.2016

Revised : 07.04.2016

Accepted : 20.04.2016

Members of the Research Forum

Associated Authors:

${ }^{1}$ Department of Fruit Crop,

Horticultural College and Research Institute, Tamil Nadu Agricultural

University, COIMBATORE (T.N.)

INDIA

${ }^{2}$ Department of Vegetable Crops, Horticultural College and Research Institute, Tamil Nadu Agricultural University, COIMBATORE (T.N.) INDIA

${ }^{3}$ Department of Remote Sensing and GIS, Horticultural College and Research Institute, Tamil Nadu Agricultural University, COIMBATORE (T.N.) INDIA

Author for correspondence : J.P. SAJITHA

Department of Vegetable Crops, Horticultural College and Research Institute, Tamil Nadu Agricultural University, COIMBATORE (T.N.) INDIA

Email : burserasaji@gmail.com
THEASIAN JOURNALOF HORTICULTURE

Volume 11 | Issue 1 | June, 2016 | 25-29

Visit us -www.researchjournal.co.in

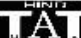

\title{
Role of nutrients on biochemical changes in various growth stages of watermelon
}

\section{J.P. SAJITHA, R.M. VIJAYAKUMAR ${ }^{1}$, L. PUGALENDHI ${ }^{2}$, D. DURGA DEVI $^{1}$ AND JAGADEESWARAN ${ }^{3}$}

ABSTRACT : An experiment was conducted to find the effect of different levels of nutrients through water soluble fertilizers along with Azophosmet and humic acid on biochemical attributes of watermelon. Application of 125 per cent of water soluble fertilizers $v i z ., 250: 125: 125 \mathrm{~kg} / \mathrm{ha}$ of NPK in addition to Azophosmet and humic acid showed the best performance in almost all the parameters studied in both seasons I and II, as it recorded the highest total chlorophyll content $\left(1.588,2.574,2.426\right.$ and $2.162 \mathrm{mg} \mathrm{g}^{-1}$ in season I and 1.652, 2.638, 2.556 and $2.379 \mathrm{mg} \mathrm{g}^{-1}$ in season II, $\mathrm{T}_{8}$ recorded the highest soluble protein content $\left(6.02,11.66,11.19\right.$ and $8.42 \mathrm{mg} \mathrm{g}^{-1}$ in season I and $6.18,12.24,11.58$ and $9.14 \mathrm{mg} \mathrm{g}^{-1}$ in season II, nitrate reductase activity at all days observed during both seasons viz., season I and season II ( 9.29, 16.89, 14.0,9.11 $\mu \mathrm{g} \mathrm{NO}_{2} \mathrm{~g}^{-1} \mathrm{~h}^{-1}$ and 9.74, $17.24,14.35$ and $9.46 \mu \mathrm{g} \mathrm{NO}_{2} \mathrm{~g}^{-1} \mathrm{~h}^{-1}$ at $30^{\text {th }}, 45^{\text {th }}, 60^{\text {th }}$ and $75^{\text {th }}$ DAS. IAA oxidase was the highest at $30^{\text {th }}$ DAS and declined at $45^{\text {th }}, 60^{\text {th }}$ and $75^{\text {th }}$ DAS in both the seasons.

KEY WORDS : Watermelon, Water soluble fertilizer, Azophosmet, Humic acid, Chlorophyll content, Soluble protein content, Nitrate reductase activity, IAA oxidase activity

HOW TO CITE THIS ARTICLE : Sajitha, J.P., Vijayakumar, R.M., Pugalendhi, L., Devi, D. Durga and Jagadeeswaran (2016). Role of nutrients on biochemical changes in various growth stages of watermelon. Asian J. Hort., 11(1) : 25-29, DOI : 10.15740/HAS/TAJH/11.1/25-29. 